Contemporary Research in Education and English Language Teaching

ISSN: 2641-0230

Vol. 3, No. 1, pp. 9-20

2021

Publisher: Learning Gate

DOI: 10.33094/26410230.2021.31.9.20

(C) 2021 by the authors; licensee Learning Gate

\title{
Reflections on the Drive to Return Mission Schools to their Owners in Nigeria
}

\author{
Ige Akindele Matthew \\ Director, School Services, Ondo State Ministry of Education, Science, and Technology, Akure, Ondo State. Nigeria. \\ Email: dele_divine@yahoo.co.uk
}

Received: 17 June 2021; Revised: 8 July 202 1; Accepted: 30 July 202 1; Published: 23 August 2021

\begin{abstract}
The issue of whether the government in Nigeria should return the schools taken from the religious organizations over four decades ago is a topic for debate. While many are arguing that such schools should be returned to their owners, others, want the government to stay action on it. It however needs not be over-emphasized that the policy of government control of schools has to a large extent guaranteed equal educational opportunities, quality education provision, increased access to education, religious tolerance, and improved national unity. When viewed from another perspective, can Nigeria afford to take another risk by returning the schools to the Missions, more so that issues of unemployment, high cost of education, religious intolerance, among others, are prevalent in the country, which the return of the schools will promote to a high level? In this paper, the roles which the Christian Missions played in the educational system were examined while the arguments for and against this initiative were examined. It is hopeful that with adequate financing, effective supervision of schools, standards put in place by the government, the agitation of people for the return of schools to the original owners will become history.
\end{abstract}

Keywords: Reflection, Drive, Return, Mission, School, Mission-School, Owner.

\section{Introduction}

The important roles which education play in the development of an individual and a nation, cannot be overemphasized, and have continued to showcase it as a little bride in every nation. Over the years, the need to provide education for the citizens of every nation, to achieve greatness, eradicate illiteracy, as well as enjoy the dividends inherent in it, has been a global crusade. The year 1842 will however remain a watershed in the annals of Nigeria, being the year western education was introduced into the country, amid the traditional and Islamic education in vogue then. Since the advent of western education, through the concerted efforts of the Christian Missionaries, it has continued to show remarkable growth in number while its administration has been under the tutelage of different governments.

At the onset, education was under the exclusive control of the Christian Missionaries, who were directly in charge of everything concerning it. They established schools, financed such schools solely, as well as monitored the schools for quality control. At this period also, the colonial governments showed a carefree attitude toward education because they considered it not to fall within their priority list (Adesina, 1977; Fafunwa, 1974). The period of exclusive control of education by the Christian Missionaries was followed by the period of dual control, which involved the Christian Missionaries and the colonial governments. At this period, the administration of the educational system was strictly guided by ordinances, released at different times during the period. Also, financing of the schools was achieved through the provision of grants which were not only infinitesimal but based on certain criteria. According to Okunola, Oyebade, and Oladipo (2005), the grants-in-aid were based on the school's performance in external examinations. Also, two different kinds of schools were in vogue, the assisted (those supported by grants-in-aid) and the non-assisted schools (those 
that were not supported by grants-in-aid). At a time during the period, the government took the initiative to establish its full-fledged schools, tagged the 'government schools' which were fully financed and administered by the colonial government. The period of dual control of education was followed by the period of control by the regional governments, occasioned by the division of the country into regions, before the introduction of another constitution in support of it (i.e. Macpherson Constitution). It is noteworthy that at this period, the administration of education became the responsibility of the regional governments which then included the western, eastern, and northern regions. A remarkable feature of this period was also the inculcation of policies and programs as well as the liberalization of education, through the establishment of additional schools and widening of enrolment which eventually exposed many children of school-age to education.

Also, there was the period of military intervention (i.e. when the military governments were in control of the educational system) which spanned from the pre-independence to the post-independence period. It is worthy of note that Nigeria attained independence status in 1960 which created self-identity for it and freed it totally from the tutelage of the colonial and foreign governments. The period also witnessed the promulgation of decrees to control the system. A remarkable feature of the military government came in 1970 when all the schools earlier established by the different missions were taken over by the government, due to the lopsidedness observed in the policy formulation and administration across the country, coupled with the disparity in enrolment, among other factors (Adesina, 1977). Also of interest was the report of Okunola et al. (2005) which confirmed that there was a public outcry against the missionary schools which resulted in the setting up of different commissions that favored full control of education by the government, one of these being the Banjo Commission The advent of democratic government added another chapter into the administration of education in Nigeria, where education became a weapon for the campaign among the political parties, As of date, education is under the control of the democratic governments, at the local, state, and federal levels.

\subsection{What are the Mission Schools?}

Mission Schools are those schools originally established and managed by the Christian Missionaries, such as the Roman Catholic Mission (RCM), Church Missionary Society (CMS); Methodist Mission, Baptist Mission, among others. The schools were established to carry out charitable work and promote Christianity. The Christian Missionaries were thus the evangelists who came mainly from Western Europe and specifically, the Portuguese and British. According to Adesina (1977), Thomas Birch freeman and William de Graft were the first missionaries of the Wesleyan Methodist Mission who came to Nigeria, specifically in Badagry in 1842, established a primary school, thus setting the pace for primary and western education in Nigeria. This attempt was followed by the CMS four years later, where a school was established in the same Badagry and another in Abeokuta. In 1855, Baptist Mission established two schools, i.e. at Lagos and Ogbomoso. These were complemented by the Roman Catholic Mission in 1860 which also opened a school in Lagos. Other missionaries followed suits, such as the United Presbyterian Church of Scotland, led by Reverend Hope Wadell who opened a school in Calabar in 1846 and another in 1847. These institutions served as the forerunners of schools/educational institutions in Nigeria.

Table-1.

Primary Schools Established by Missions in Nigeria as of 1913.

\begin{tabular}{l|c}
\hline Mission & No of Schools Established \\
\hline African Church & 2 \\
\hline Church Missionary Society & 27 \\
\hline Methodist & 1 \\
\hline Qua-Ibo & 26 \\
\hline Roman Catholic Mission & 19 \\
\hline United Free Church of Scotland & \\
\hline \multicolumn{2}{l}{ Source: Ojebiyi and Onoguere (2016). }
\end{tabular}


As shown in Table 1, the Church Missionary Society had the highest number of schools (27) as of 1915, followed by the Roman Catholic Mission (26), and the United Free Church of Scotland (19). The least schools were however owned by Qua-Ibo (1) while African Church had only 2 schools then.

Table-2.

Secondary Schools Established by Missions in Nigeria as of 1908 .

\begin{tabular}{l|l|l|l}
\hline Mission & School & Location & $\begin{array}{l}\text { Year } \\
\text { Established }\end{array}$ \\
\hline $\begin{array}{l}\text { Church Missionary } \\
\text { Society }\end{array}$ & $\begin{array}{l}\text { CMS Grammar School } \\
\text { Abeokuta Grammar School }\end{array}$ & $\begin{array}{l}\text { Lagos } \\
\text { Abeokuta }\end{array}$ & 1859 \\
$\begin{array}{l}\text { Roman Catholic } \\
\text { Mission }\end{array}$ & Saint Gregory College & Lagos & 1876 \\
\hline Methodist & Methodist High School & Lagos & 1879 \\
\hline Baptist & Baptist Boys High School & Lagos & 1885 \\
\hline Church of Scotland & Hope Wadell Institute & Calabar & 1895 \\
\hline Source: Ojebiyi and Onoguere $(2016)$. & &
\end{tabular}

In Table 2, it is indicated that as of 1908, only six mission schools were in existence. While the Church Missionary Society owned 2, only one was owned by the Roman Catholic Mission., Methodist Mission, Baptist Mission, and Church of Scotland.

\subsection{Status of the Quest for Return of Mission Schools in Nigeria}

Although the controversy surrounding the issue of the return of Mission Schools to their owners rages, there are reports that some of the schools had been returned in some states. For example, in Delta State, 40 schools were returned to the missions, 27 to the Catholic Mission; 8 to the Anglican Mission; 4 to the Baptist Mission, and 1 to the African Church (in CT, https://www.christianitytoday.com/ct/2012/june/nigeria-fury-over-fees.html). Another report (The Nation. August 28, 2019) indicates that Cross River State has returned 6 primary schools to their original owners i.e. Catholic Church. While in Anambra State, 6 schools were earlier returned to the different churches as a pilot scheme, by the predecessor government, but in 2011, the state returned all the 1,040 schools to the churches that originally established them (The Sun, 10 September 2019). In 2016, Oyo State returned their schools while Ekiti State kickstarted this with the return of one of the oldest secondary schools in the state to the Anglican Communion. (NNN News, September 16, 2019). Apart from those already returned, the effort is ongoing in some states to return their schools while some states are still confused or in a state of dilemma and have been subjecting the idea into a debate until they are fully convinced about the need to return such schools.

\subsection{Arguments In Support of the Return of Mission Schools}

In Nigeria, the issue of the return of Mission Schools to the rightful owners has been a controversial one. It is a fact that those who are clamoring for the return of such schools have their reasons why they are supporting such an idea, such as:

\subsubsection{High Cost of Running Schools and Poor Funding of Education}

Over the years, funding has remained the main issue in the educational system of Nigeria. It is a fact that the bulk of funds for the management of education in Nigeria comes from the government, through the annual budgetary allocation. Funds for the education sector have however been inadequate in quantity and epileptic in supply (Ige, 2016). This problem of poor funding of education has not however developed overnight but as old as the system, being traceable to the period when education was under the aegis of the Christian Missionaries (Adesina, 1977). At this time, the main motive was to use education to promote evangelism. It is in light of this that the colonial governments paid lip service to 
its funding. For almost four decades (1842-1882), funding of education was left exclusively for the Christian Missionaries which they initially achieved through the collection of offerings, donations from philanthropists, and grants from headquarters of the Missions (Adesina, 1977; Fafunwa, 1974) but later achieved through grants from the colonial governments and fees. The report further indicates that in 1872, a token sum of $£ 30$ was released for the missions that operated schools in the Lagos Colony at the time (i.e. Wesleyan Methodist Mission, Church Missionary Society, and the Roman Catholic Mission) which was then shared equally among the three missions. Between 1874 and 1876, an annual grant of $£ 300$ was released to the same three missions, which was increased to $£ 600$ in 1877 (Fafunwa, 1974). At a time when it was noticed that the available funds were inadequate, the missions resorted to charging fees that ranged from 4 to 6 pence a month in the primary and 4 to 6 guineas a year in grammar school (Adesina, 1977) As at the time government deemed it fit to join the Christian Missions in funding education, participation was not in totality, as grants were then given to the selected schools which were later modified to be according to established criteria (Adesina, 1977; Fafunwa, 1974). It implies from these antecedents that education has not been having it smooth in Nigeria, in terms of funding. The poverty of education which was prevalent during the early years, as a result of the poor funding, has been the basis and foundation of the continued poverty of the educational system till today. It is not doubtful that over the years, federal and state governments have been injecting huge funds into education (Table 3 as reference), to ensure that there is increased access of the citizens to it and that qualitative education is provided for the citizens. Apart from the cost of paying the salaries and allowances of the teachers and non-teachers, provision has to be made for the purchase of facilities, instructional materials, among others. Going by the state of the economy, it is now a yoke for government to continue to be the sole provider of funds for the education sector. It is thus believed that the return of schools to the missions will ease the burden of government on the education sector. A lot of funds will be saved which can be utilized for the other sectors of the economy.

Table-3.

Federal Government Budgetary Allocation to Education as \% of Total Budget: 2009-2019.

\begin{tabular}{c|c|c|c}
\hline Year & Budget(Ntr) & $\begin{array}{c}\text { Education Allocation } \\
(\mathbf{N b n})\end{array}$ & \% of Total Budget \\
\hline 2009 & 3.049 & 221.19 & 7.25 \\
\hline 2010 & 5.160 & 249.09 & 4.83 \\
\hline 2011 & 4.972 & 306.3 & 6.16 \\
\hline 2012 & 4.877 & 400.15 & 8.20 \\
\hline 2013 & 4.987 & 426.53 & 8.55 \\
\hline 2014 & 4.962 & 493 & 9.94 \\
\hline 2015 & 5.066 & 392.2 & 7.74 \\
\hline 2016 & 6.061 & 369.6 & 6.10 \\
\hline 2017 & 7.444 & 550 & 7.38 \\
\hline 2018 & 8.612 & 605.8 & 7.03 \\
\hline 2019 & 8.83 & 620.5 & 7.05 \\
\hline
\end{tabular}

As indicated in Table 3, allocation to education in Nigeria has been grossly below the $26 \%$ of the Gross Domestic Product (GDP), recommended by the United Nations Educational, Scientific and Cultural Organisation (UNESCO) which is an indication that education in Nigeria is grossly underfunded.

\subsubsection{Insufficient Infrastructural facilities in Schools}

Infrastructural facilities are germane in the provision of education for a child. Unfortunately, the state of these in the educational system of Nigeria leaves much to be desired. This issue has however been an aged one, having started during the period when education was under the aegis of the 
Christian Missionaries. At this period, the colonial government did not show any concern for it. It was then funded solely by the Christian Missionaries, through regular Sunday collections, philanthropic donations, and reimbursements from overseas headquarters of the different Churches (Adesina, 1977; Fafunwa, 1974) Due to the inadequacy of funds for education development then, classrooms were inadequate for pupils and students while most of the available ones were in a state of disrepair. There were even reports that during this period, some pupils received lessons under trees (Adesina, 1977; Fafunwa, 1974). The issue of inadequate infrastructural facilities has remained with the educational system till today.

\subsubsection{Negative Morality of Pupils/Students in Schools}

The moral standards in Nigerian schools are now at the lowest ebb. It is thus not surprising that Adedigba and Wahab (2015) lamented the alarming rate of decline in moral consciousness and conducts among Nigerians, which has become a disease that is eating into the veins of the country, and eroding the qualities and potentials needed in the Nigerian future leaders (i.e. students). It is therefore not a gainsaying that life in present-day Nigerian schools shows a lack of moral consciousness which is reflecting in increased cases of students fighting, truancy, hooliganism, involvement in examination malpractices, cultism, disobedience, rioting, disregard for constituted authorities, and other imaginable and unimaginable immoral behaviors which are becoming entrenched in Nigeria public life, and which without doubt, has, in turn, contributed in no small measure to the lowering of the educational standard in Nigeria. Generally, some proponents of government views on the take-over of schools, have attributed the falling standard of education, moral laxity, inconsistency in values, to the Nigerian civil war while others attributed the new development to the uncontrolled and unplanned explosion of the school population, societal diseases, imported cultures, and not government take-over of school. Undisputedly, since the government's take-over of schools, both the intellectual and moral development of the Nigerian child has been largely placed in the hands of the government. Consequently, in the public schools' curricula, religious education is now optional or completely dropped. This is because some government educational planners felt that such a concept was not only inimical and foreign to our culture but an attempt to indoctrinate the youths. To this end, the drop or operationalization of the teaching of religious and moral education in Nigerian schools has created a very wide gap in the proper upbringing of the Nigerian child and the gap has continued to widen over time. Ezeanya (1976) emphatically argued that sound education must include religion. As of date, Nigeria is at the height of corruption and crime, unlike the period when religious education had pride of place in the school curriculum and was handled by dedicated teachers who helped to instill discipline and the fear of God in the students.

\subsubsection{Low Commitment/Productivity of Teachers}

It is a fact that teacher plays an invaluable role in the educational system. According to William and Edet (2014) teachers occupy a very strategic position in the educational system and are catalysts of national development and progress, which is buttressed by the assertion of Obanya (2005), cited in Ogunsanya (2012) that:

Teachers are essential players in promoting quality education whether in schools or more flexible community-based programs, they are advocates for, and catalysts of change. No education reform is likely to succeed without the active participation and ownership of teachers.

What is noticeable in public schools in Nigeria now, is a situation whereby a lot of teachers are not committed to the job. Such teachers are fond of displaying a lackadaisical attitude to work. There are reports of the negative attitude of teachers in service in Nigeria, such as late-coming to school and classes, absenteeism from school (Ejere, 2010; Patrinos, 2013), non-keeping and late-keeping of records, as well as poor management of records (Agenyi, 2013; Daniel, 2015; Ige, 2013), poor attitude to work and habit of not willing to teach but the collection of free salary (Daniel, 2015), extortion of illegal 
money from students (Daniel, 2015), taking bribe from students (Daniel, 2015), indulgence in unwholesome practices in and outside school, such as commercial diving (Ige., 2011), trading (Kanu \& Ursula, 2012), examination malpractices (Adeyemi \& Ige, 2002; Alonge \& Ige, 2015), drug and alcohol taking (Babalola, Ighoroje, Awhangansi, \& Ayilara, 2017), just to mention a few, which are impacting negatively on their productivity in schools. It is therefore a truism that in public schools these days, many teachers are cheaters. They just wait till the end of the month to collect their emoluments which they have not worked for. Many teachers rather than being on their feet in the classroom are always on their wheel. It is thus believed that if the Mission Schools are returned to the owners, these cannot be tolerated. There is thus bound to be an improvement in the service delivery of the teachers because the proprietors will handle them strictly unlike when they were in the public service.

\subsection{Arguments against the Return of Mission Schools}

There are issues are at stake which must be resolved first before the decision to return the Mission Schools to the original owners in Nigeria should be taken, such as:

\subsubsection{Insufficient Teachers and High-Level Unemployment}

Adelakun (2009) and Achimugu (2005) buttressed the fact that teacher plays a vital role in the education of pupils and students. No educational system can succeed without the availability of qualified and committed teachers. Since the advent of western education in Nigeria, the issue of teacher insufficiency has been a major challenge. This has been so grave in primary and secondary schools. Statistics, as confirmed by data in Table 4, revealed that the harvest is plenty in Nigeria but the laborers (teachers) are few. Adesina (1977) and Adeyem (1998) reported that at the onset, teachers were negligible in quantity and poor in quality.

Table-4.

Teachers Statistics in Public Primary Schools in Nigeria: 2012-2017.

\begin{tabular}{c|c|c|c|c}
\hline Year & $\begin{array}{c}\text { No of } \\
\text { Teachers }\end{array}$ & $\begin{array}{c}\text { No of Qualified } \\
\text { Teachers }\end{array}$ & $\begin{array}{c}\text { \% of Qualified } \\
\text { Teachers }\end{array}$ & $\begin{array}{c}\text { \% of Unqualified } \\
\text { Teachers }\end{array}$ \\
\hline $2012 / 2013$ & 536,734 & 329,826 & 61.45 & 38.55 \\
\hline $2013 / 2014$ & 515,401 & 407,625 & 79.09 & 20.91 \\
\hline $2014 / 2015$ & 523,429 & 410,231 & 78.37 & 21.63 \\
\hline $2015 / 2016$ & 453,248 & 354,256 & 78.16 & 21.84 \\
\hline $2016 / 2017$ & 472,077 & 345,801 & 73.25 & 26.75 \\
\hline
\end{tabular}

Source: Federal Republic of Nigeria (2017).

The missionaries, their wives, and acquaintances were involved in the teaching of pupils in the earliest schools. Many teachers were then not only un-certificated but lacked the pedagogy of teaching. The report of the Ashby Commission which was set up in 1959, to examine the manpower needs of the country for twenty years after the attainment of independence (i.e. 1960-1980) captured the ugly situation, having revealed that 80,000 teachers were in schools than with about three-quarters of them un-certificated. Even among the certified teachers, only one-third had education beyond the primary level (Adesina, 1977; Fafunwa, 1974). What this implies is that the quality of education which pupils and students received during the period of stewardship of the Christian Missionaries, fell short of expectation.

In Table 4, data on the number and percentage of qualified and unqualified teachers, relative to the number of available teachers, in the primary schools in Nigeria, from the year 2012 to 2017, are shown. As indicated in the table, the number of qualified teachers during the period ranging from 329, 826 (in 2012 ) to 410, 231 (in 2014. Also, percentage of qualified teachers ranged from $61.45 \%$ to $78.37 \%$ while the percentage of unqualified teachers ranged from 20.91 (in 2013) to 38.559 in 2012). The data thus revealed a fluctuating trend in the number of qualified teachers, percentage of qualified and unqualified teachers in Nigeria during the period. 
It is not doubtful that the Mission Schools if eventually returned, will be run like private schools, where the emphasis will be on profit-making. The missions will wish to maximize profit by using fewer resources to achieve the desired goals. There is the possibility that as the schools are returned to the missions, they will reduce the teachers handed over to them or sack the majority of them and recruit new ones, to create a self-identity and reduce redundancy and wastage which are noticeable in the public schools. This will even be done to reduce the cost of payment of salaries and allowances. They will also formulate a fresh recruitment policy to guide the recruitment of teachers into their schools. This thus implies that a lot of teachers may be relieved of their job and sent back to the labor market which is already turgid of unemployed youths, which may worsen the unemployment situation in the country. It is unfortunate that at present, securing a job by a graduate of any tertiary institution in Nigeria has been a difficult task. Over the years, the issue of unemployment of able-bodied youths who are graduates of tertiary institutions has been a nightmare in the country.

Table-5. Unemployment Rate in Nigeria from 1999 to 2019.

\begin{tabular}{c|c|c}
\hline Year & Unemployment Rate (\%) & Annual Change \\
\hline 2018 & 8.24 & $-0.15 \%$ \\
\hline 2017 & 8.39 & $1.33 \%$ \\
\hline 2016 & 7.06 & $2.75 \%$ \\
\hline 2015 & 4.31 & $-0.25 \%$ \\
\hline 2014 & 4.56 & $0.86 \%$ \\
\hline 2013 & 3.7 & $-0.03 \%$ \\
\hline 2012 & 3.74 & $-0.04 \%$ \\
\hline 2011 & 3.77 & $0.00 \%$ \\
\hline 2010 & 3.77 & $0.04 \%$ \\
\hline 2009 & 3.72 & $0.18 \%$ \\
\hline
\end{tabular}

Source: World Bank, 2020.

As indicated in Table 5, the unemployment rates during the period 1999 to 2019 ranged from $3.17 \%$ (in 2013) to 8.39 (in 2017). The rates however showed fluctuating trends during the period.

As it is often said that 'an idle hand is the devil's workshop', many of these people may result to indulgence in crime which will further increase the tension in the country, already turgid of vices, such as prostitution, armed robbery, kidnapping, swindling, just to mention a few, which will make the country to be saying goodbye to peace in this period of its history.

\subsubsection{Likely Variation in Curriculum}

Ker (1962); Caswell \& Campbell (1935), cited in Oloruntegbe (2003) confirmed the importance of curriculum in the teaching-learning process. There are criticisms of the curriculum of education in Nigeria (Ige, 2019). Arguments against the curriculum are the fact that it is inappropriate, nonfunctional, and irrelevant to the needs of the labor market, as well as the country at large. The problems of the curriculum in Nigeria have however not developed overnight but could be traced to the period when the Christian Missionaries were in control of the educational system. It is worthy of note that the main motive for introducing education by the missionaries then, was to use it as a tool for the conversion of people into Christianity which was then their 'pet project'. The curriculum was then primitive and shallow in scope and contents. Report (Ajayi \& Ajayi, 1989) indicates that the curriculum then consisted of subjects like Reading, Writing, Singing, Bible knowledge, and English, which later included Arithmetic, British Geography, and Culture (Aghenta. (1984), cited in Ajayi and Ajayi (1989). Also, the curriculum failed to address the needs and problems of the country. As of then, the country did not have adequate skilled manpower for the development of its economy which was then tied to the apron of the foreign missions. It was thus expected that the curriculum will be able to produce skilled manpower who will contribute to the growth and development of the underdeveloped economy. Rather 
than tailoring the curriculum to these needed areas, emphases of the Christian Missions were focused on the training of people that would perform different roles in the churches. It was thus the general dissatisfaction with the existing educational structure, particularly the irrelevancy of the curriculum to national needs, aspirations, and goals that culminated in the National Curriculum Conference of 1969, which provided opportunities to re-define the aims and contents of education in Nigeria and later, the National Policy of Education of 1977, as well as the "6-3-3-4 system of education. It is therefore being argued that the return of Mission Schools will continue to encourage varied and irrelevant curricula to thrive in the educational system. The author observed that most private schools in Nigeria are dissatisfied with the curriculum of education produced by the government. Apart from being unstable which has become its major characteristic, the contents are incongruent to what they desire from students. It is therefore not a surprise that a lot of primary and secondary schools owned by private individuals, corporations, and religious bodies, are fond of copying the foreign curriculum, for example, the British Curriculum, to make them different from Nigeria. Most parents prefer such schools that are operating foreign and advanced curriculum to the national curriculum. It has even become a norm that topics in the advanced classes are taught in the lower classes in such schools, to create the impression that they are better in academics, Parents in such schools see the government curriculum to be too simple and less challenging. There is therefore no gainsaying that the more schools are returned to the missions, the more the curriculum of education will continue to be divergent.

\subsubsection{Likely Variation in Education Policies and Standards}

Education policies provide the framework for the effective management of the educational system. During the period when the Christian Missionaries were in total control of the educational system, there was no uniformity of standards and policies in schools being operated by the missions (Adesina, 1977; Fafunwa, 1974). Each mission was reported to have implemented different policies to control the schools under its care. The take-over of schools has achieved to a large extent, the unification, central control, better funding, and management of the educational system.

\subsubsection{Promotion of Church's Doctrine}

Over the years, the governments in Nigeria have continued to emphasize the need for all schools to be non-denominational. Religious instruction is thus to be taught in schools only on a nondenominational basis. If schools are therefore returned to the owners, there is every possibility for the missions to subject the students to adherence to their religious doctrines which if allowed, will erode the secularism of education, as being practiced in the country presently. This may therefore worsen the religious intolerance which has been a feature of Nigeria over the years and will continue to threaten the nation's stability and unity.

\subsubsection{Likely High Fees Payable}

In Nigeria, much respect will be accorded you if your child is enrolled in one of the Mission Schools where a high fee is paid, even though most of those having children in such expensive schools are those whose salaries are incongruent with their lifestyle and with the fee chargeable in the schools. It is thus a confirmation of the high level of corruption in the country. A report indicates that tuition fee at churchrun primary schools in Nigeria presently ranges from 15,000 to 50,000 naira ( $\$ 100-\$ 350)$ per term. Unfortunately, presently, the minimum wage for those in the public service in Nigeria is N18, 000 nairas or a little above it (in some states), which translates to $\$ 120$ per month. It is even unfortunate that most of these Mission Schools were built from offerings and tithes collected from their worshipers. Quite unfortunate is the fact that as soon as the schools are established and become operational, the worshippers are ostracized from such schools even a lot of church members may not be able to enroll their children in such schools. The implication of this is that if schools are returned to the owners, fees will increase. The missions will charge a heavy fee to garner money for the sustenance of the schools, which may therefore make many children not have access to education in this decade and beyond and 
continue to draw the country backward in its attempt to achieve Universal Basic Education for the children, as well as the Sustainable Development Goals.

\subsubsection{Likely Poor Remuneration and Motivation of Teachers}

Remuneration is an important issue when it comes to the issue of the motivation of teachers. The average teacher believes that when the salary is high and paid as and when due, he/she will be encouraged to work more and even better. The author observed that in Nigeria, private schools are fond of paying less for their teachers and non-teachers, unlike their counterparts in government-owned schools. Apart from the low wage which they receive from their proprietors, they are subjected to different kinds of extracurricular activities which do make them be alienated from their family members. A lot of these teachers and non-teachers, run errands for their proprietors and worst of it, are used in domestic activities of their masters. Since a beggar has no choice, such workers have to accept their fate since there is no alternative for them to be able to keep the body and soul together. A threat of sack awaits anyone who dares challenge his/her master on these inhuman treatments. If schools are therefore returned to the missions, such disposition will persist. The missions may not be able to pay the same wage as the government and may thus resort to the sacking of some of the teachers inherited from the government. They will like to fix their affordable wages for the teachers and non-teachers, apart from derecognizing those motivational measures already put in place by the government which may therefore worsen the status of teachers in the society. There are even report that majority of government teachers have refused employment in the returned schools, protesting that church operators are too strict and profit-oriented.

\subsection{Reflections on the Drive to Return Mission Schools in Nigeria}

In this paper, arguments had been raised in favor of and against the return of Mission Schools to their owners in Nigeria. In some cases, issues raised are supported by qualitative and quantitative data. Be that as it may, it is worthy to point out that Nigeria is a country that is plagued by issues, a major one being the out-of-school children syndrome, which implies that while the country is striving to achieve holistic access to education, many children of school- age are not having access to it. Having realized this, efforts are being geared towards ensuring that the out-of-school children are captured and sent to school. Unfortunately, Nigeria has been taking one step forward and two steps backward. Why Government is looking at the perspective of funds majorly in its decision to return the schools to the owners, little does it realize that it goes beyond this issue of funding. Some factors were prevalent during the period when the schools were taken over by the missionaries but are still prevalent today. The gains being envisaged to be reaped from the return of the schools may therefore be usurped by other factors that are not taken into cognizance. For example, how can it be explained that the government is returning schools to the owners who will eventually charge heavily, which is bound to send many students packing from schools and deny a lot of children from having access to education

Unemployment is another issue of concern. In Nigeria today, the idea of attending school/educational institutions to get/secure a white-collar job at the end is now a mirage. Many ablebodied youths are hopelessly wandering about the major streets in Nigeria, in search of non-existing jobs. It is quite disturbing to note that street-begging has become the order of the day. In Nigeria now, you don't need to be disabled before you beg for money from people. There are now a lot of certificated and corporate beggars along the streets, no thanks to the unemployment pandemic which in no distant time will overcome the now dreaded COVID-19 pandemic. Many of the youths are also venturing into kidnapping. Unfortunately, kidnapping is now a serious and very lucrative business in Nigeria. Innocent citizens are now at the mercy of the unemployed youths but misnamed kidnappers.

It is also a fact that the issue of the return of schools is being politicized in Nigeria. Good as the issue is, the government is not taking precautionary measures to ensure that there is no regret in the end. Can the missions cope with the schools being returned to them? Will policies be adhered to? These are the food for thought which must be addressed if the expected dividends or joy from the return of the 
schools to the owners will not be a mirage in the end. With the return of the schools, it is obvious that education is being privatized. Many children may not have access to education in this decade and beyond. Nigeria cannot afford to be playing politics with education because of the consequences it will have on the people and the society at large.

\section{Conclusion}

It is a fact that as of today, Nigeria is plagued by problems, such as high-level unemployment, outof-school children syndrome, among others. Over the years, the country has been striving to achieve equity, egalitarianism, Education for All, as well Sustainable Development Goals, in line with the global crusade. While it cannot be doubted that the Christian Missionaries left their footprints in the sand of time, having contributed immensely to the laying of a solid foundation for education development in Nigeria, the drive to return the schools taken from them needs to be taken with caution because the forces which necessitated this are still in vogue till today. In the light of the issues argued in this paper, returning schools to the missions, rather than ameliorating the situation, will aggravate it as it will promote to high esteem, high-level unemployment, make education inaccessible to children, as well as make the achievement of the goals of equity, egalitarianism, Education for All, as well as Sustainable Development, mirage if actualized.

\subsection{Way Forward}

The following measures are recommended, to address the consequences of not returning schools to the missions, and to be able to move education forward in Nigeria:

\subsubsection{Partnership Between Government and Missions}

Rather than return schools to the missions, the government should sustain the ownership of the schools because it is the right of the government to provide basic education for the citizens. While government should take care of the funding and monitoring of the schools, as well as policy formulation, to guide the schools, the missions should assist the government in the management of the schools, provision of infrastructural facilities, to alleviate the challenges of insufficiency and decay in the schools. Government should also initiate a regular meeting with the representative of the missions, to discuss matters affecting educational development and the way forward.

\subsubsection{Improved Funding of Education}

It is unfortunate that over the years, allocation to education in the annual budget has been grossly below the 26\% of the Gross Domestic Product (GDP), recommended by the United Nations Educational, Scientific and Cultural Organisation (UNESCO). This implies that education in Nigeria is grossly underfunded. This has led to inadequate and decayed infrastructural facilities in educational institutions. Government should therefore provide more funds for education in Nigeria. In as much as it is becoming a reality that the government alone cannot fund education in Nigeria, there $i$ a a need for wealthy parents and individuals in the society to assist the government in this regard. Donation of money, provision of facilities, scholarship and bursary for indigent pupils and students as well as the provision of services will be a welcome development. Government should also seek the assistance of international organizations, philanthropists, old students of schools, for contributions to the funding of education.

\subsubsection{Tackling Corruption Decisively}

Over the years, corruption has been the bane of the development of Nigeria, particularly the education sector. Much of the funds being allocated to the education sector, in particular, for the development of schools/educational institutions in Nigeria, are usually diverted and mismanaged. There is thus the need for the government to take stern measures against those caught to be involved in the act, to serve as a deterrent to others, and ensure that money earmarked for education development are 
spent judiciously for the development of education and not wasted.. Government should therefore empower the agencies in charge of corruption, to be able to tackle the menace appropriately.

\subsubsection{Proper Monitoring of Schools}

Government at both the federal, state, and local levels, should give more priority to the monitoring of schools, in particular, the academic activities in the schools and the behavior of students and teachers, and act promptly to the report and recommendations received from the monitoring officers. This if imbibed, will improve the quality of education being provided in the schools and checkmate the disciplinary attitudes of students and the teachers.

\subsubsection{Recruitment, Training, and Motivation of Teachers}

More teachers should be recruited and distributed to Schools while teachers should be trained regularly to improve their professional competency;

\section{References}

Achimugu, L. (2005). The agonies of Nigerian teachers. Ibadan: Heinemann Education Publishers.

Adedigba, T. A., \& Wahab, E. I. (2015). Degenerated moral values in Nigerian: Challenges of social studies education. Nigerian Journal of Social Studies, 18(1), 247-261.

Adelakun, O. (2009). Assessing quality of e-learning in developing country. Paper presented at the International Conference of Association of Science Education (ICASE) at Abuja, Nigeria.

Adesina, S. (1977). Planning and educational development in Nigeria. Lagos, Nigeria: Educational Industries Limited.

Adeyem, L. J. K. (1998). Financing public education in Nigeria. In M. Nwadiani (Ed), Educational Management for Sub-Saharan Africa. Benin City, Nigeria: Nigerian Society for Educational Planning \& Monose Amalgamates.

Adeyemi, J., \& Ige, A. A. (2002). Examination malpractices in Nigerian educational system: Causes, effects and the way out. Nigerian Journal of Clinical and Counselling Psychology, 8(1), 57-76. Available at: https://doi.org/10.4314/njccp.v8i1.23915.

Agenyi, E. (2013). Record keeping among teachers in Nigeria secondary schools. Implications for service delivery. Journal of the International Centre for Science, Humanity and Education Research, 11(3), 51-57.

Ajayi, K., \& Ajayi, T. (1989). Trend in the development of primary education in Nigeria. In Tamuno \& J. Atanda (Eds.), Nigeria Since Independence; The first 25 Years. Ibadan, Nigeria: Heinemann Educational Publishers Limited.

Alonge, H. O., \& Ige, A. M. (2015). Strategies for tackling examination malpractices in Nigeria, from teachers Perspective. Journal of Open Learning and Teacher Education, 2(1), 105-1 17.

Babalola, E., Ighoroje, M., Awhangansi, S., \& Ayilara, O. (2017). Psychosocial correlates of hazardous alcohol use among secondary school teachers in Southwestern Nigeria. International Journal of Psychiatry in Clinical Practice, 5(1), 17-23.

Daniel, W. D. (2015). Identifiable corrupt practices among staff and students of secondary schools in Delta State of Nigeria. International Journal of Secondary Education, 3(5), 50-54. Available at: https://doi.org/10.1 1648/j.ijsedu.20150305.12.

Ejere, E. I. (2010). Absence from work: A study of teacher absenteeism in selected public primary schools in Uyo, Nigeria. International Journal of Business and Management, 5(9), 115. Available at: https://doi.org/10.5539/ijbm.v5n9p115.

Ezeanya, S. (1976). Religion in Nigeria schools. Nigerian Tide, Dec 15.

Fafunwa, B. A. (1974). History of education in Nigeria. London: George Allen and Unwin Ltd.

Federal Republic of Nigeria. (2017). Digest of education statistics. Abuja: Federal Ministry of Education.

Ige, A. M. (2013). Records keeping and management in primary and secondary schools in Nigeria issues, challenges, and way forward. Nigerian Journal of Professional Teachers, 3, 169-179.

Ige, A. M. (2016). Financial allocation to education: Trends, issues, and way forward in Nigeria. Journal Plus Education, 14(1), 228-243.

Ige, A. M. (2019). Reflections on provision of primary education and way forward in Nigeria. Journal of Educational Research and Evaluation, 3(2), 105-114. Available at: https://doi.org/10.23887/jere.v3i2.17211.

Ige., A. (2011). Myths and realities of falling standard of education in Nigeria: The way forward. Nigerian Journal of Professional Teachers, 2, 36-48.

Kanu, S. I., \& Ursula, N. A. (2012). Unethical practices in the Nigerian educational system. Interdisciplinary Journal of Contemporary Research in Business, 4(8), 451-464.

Ogunsanya, M. (2012). Teacher image and teacher transformation in a corrupt society. In Aminu, L.S (Ed). Enhanced teacher education and professional development Paper presented at the Proceedings of the 3rd National Teachers Institute Summit, held at Kaduna, 8th-9th Novembers.

Ojebiyi, O. A., \& Onoguere, E. O. (2016). Christian missions and the implantation of Western education in the pre-and postcolonial Nigeria. African Journal of School Business, 1(2), 60-72. 
Okunola, P. O., Oyebade, S. A., \& Oladipo, S. A. (2005). Return of schools to private managers in Lagos State: Implications for quality amid change. Paper presented at the 29th Annual National Conference of the National Association for Educational Administration and Planning (NAEAP).

Oloruntegbe, K. O. (2003). Curriculum: Concept, development, implementation, and revision. Nigeria: Ikare-Akoko; Calvary Ways Publishers.

Patrinos, H. A. (2013). 8 The hidden cost of corruption: Teacher absenteeism and loss in schools. In Global corruption report: Education (pp. 94-97): Routledge.

William, E. E., \& Edet, A. O. (2014). The role of teacher education and Nigerian teachers in national development: The way forward. Higher Education of Social Science, 7(1), 139-143. 